\title{
Loftmengun á Íslandi og áhrif hennar á heilsu manna
}

\author{
Yfirlitsgrein
}

Gunnar Guðmundsson¹,2 læknir

\author{
Ragnhildur Guðrún \\ Finnbjörnsdóttir ${ }^{3,4}$ lýð̌heilsufræðingur
}

\section{Porsteinn Jóhannsson ${ }^{3}$ umhverfisfræðingur}

\section{Vilhjálmur Rafnsson ${ }^{4}$ prófessor emeritus}

\begin{abstract}
${ }^{1}$ Lungnadeild Landspítala, ${ }^{2}$ rannsóknastofu í lyfja- og eiturefnafræði, læknadeild

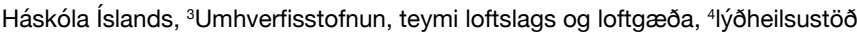
læknadeildar Háskóla Î́slands
\end{abstract}

Fyrirspurnum svarar Gunnar Guðmundsson, ggudmund@landspitali.is

\section{Inngangur}

Mengun er skilgreind í íslenskum lögum um hollustuhætti og mengunarvarnir frá 1998 sem „pað pegar örverur, efni og efnasambönd og eðlisfræðilegir pættir valda óæskilegum og skaðlegum áhrifum á heilsufar almennings, röskun lífríkis eða óhreinkun lofts, láðs eða lagar". ${ }^{1}$ Loftmengun verður par sem styrkur efna eða efnasambanda í andrúmslofti er orðinn pað hár að hann veldur óæskilegum eða skaðlegum áhrifum á heilsu almennings eða óæskilegum áhrifum á náttúru, lífríki eða mannvirki. Hún getur verið af völdum manna eða náttúruleg eins og í eldgosum, á jarðhitasvæðum og í foki jarðvegsefna. ${ }^{2}$ Áhrifum loftmengunar á heilsu manna má skipta í bein áhrif par sem loftmengunin veldur sjúkdómum og óbein áhrif par sem loftmengunin eykur einkenni undirliggjandi sjúkdóma. Loftmengun er hættuleg heilsu manna, einkum peirra sem pjást af sjúkdómum í öndunarfærum og hjarta og æðakerfi. Loftmengun dregur úr lífsgæðum og lífslíkum manna. Börn eru sérstaklega viðkvæm, pví loftmengun getur valdið öndunarfærasjúkdómum hjá peim og haft varanleg áhrif á lungnaproska barna. Pað getur skipt máli síðar á ævinni.

Heilsuverndarmörk eru skilgreind fyrir ákveðin loftmengunarefni í andrúmslofti og eru hugsuð fyrir almenning, bæði börn og fullorðna, sjúka sem heilbrigða. Peim er ætlað að vera viðmiðun fyrir hvað telst skaðlaust fyrir einstaklinginn og eru sett til að tryggja heilsu manna til lengri tíma.

Loftgæði eru talin mikil á Íslandi og er styrkur mengunarefna í andrúmslofti að jafnaði innan skilgreindra viðmiða ef frá er talið svifryk. Petta skýrist af stærð landsins, legu pess, fáum íbúum og veðurfari. Náttúruhamfarir geta aftur á móti ógnað loftgæðum landsins. Eldgos eru hér tíð og reynslan hefur sýnt að loftmengun af völdum peirra getur verið mikil og haft áhrif á heilsufar manna. ${ }^{3}$ Loftgæði bötnuðu til muna í péttbýli á Íslandi pegar hætt

\section{Á G R I P}

Í pessari grein er fjallað um loftmengun á Íslandi og áhrif hennar á heilsu manna. Loftmengun má lýsa sem ástandi par sem styrkur efna eđa efnasambanda í andrúmslofti er orðinn pað hár að̃ hann veldur óæskilegum eða skaðlegum áhrifum á heilsu almennings eða óæskilegum áhrifum á náttúru eðaa mannvirki. Loftmengun getur verið af manna völdum, svo sem vegna bruna jarðefnaeldsneytis, eða náttúruleg, til dæmis vegna eldgosa, frá jarðhitasvæđum og í foki jarðvegsefna. Loftmengun dregur úr lífsgæðum og lífslíkum manna. Áhrifum loftmengunar á heilsu manna má skipta annars vegar í bein heilsufarsleg áhrif par sem loftmengunin veldur sjúkdómum og hins vegar óbein áhrif par sem loftmengunin eykur einkenni undirliggjandi sjúkdóma. Heilsuverndarmörk eru skilgreind fyrir ákveðin loftmengunarefni i andrúmslofti. Peim er ætlað að vera viðmið fyrir hvað telst skaðlaust fyrir einstaklinginn og eru sett til að tryggja heilsu manna til lengri tíma.

Loftgæði utandyra hafa verið mæld reglubundið í Reykjavík síðan 1986. Fyrstu árin var eingöngu mælt svifryk á einni mælistöð sem pá var staðsett við Miklatorg. Með árunum hefur fjölgað peim efnum sem mæld eru og bæst hafa við fleiri mælistöðvar.

Loftgæði eru almennt talin mikil á Íslandi og er styrkur mengunarefna í andrúmslofti að jafnaði innan skilgreindra viðmiða. Petta skýrist af margvíslegum páttum eins og stærð landsins, legu pess og veðurfari. Náttúruhamfarir geta valdið loftmengun eins og sýndi sig í eldgosum síðustu ára. Rannsóknir hafa verið gerðar á tengslum loftmengunar viơ heilsufar Íslendinga og æskilegt er að̃ fleiri rannsóknir verði framkvæmdar til að bæta pekkinguna á loftmengun á Íslandi enn frekar.

var að nota kol og olíu til húshitunar og götur voru malbikaðar. Almennt eru bein tengsl milli fjölda bíla og loftmengunar. Hins vegar hafa ýmsir umhverfispættir, samsetning bílaflotans og mótvægisaðgerðir mikið að segja. Verulega hefur dregið úr loftmengun við Grensásveg prátt fyrir stóraukna umferð frá pví að mælingar hófust par árið 1994. Meginorsök minni svifryksmengunar er talin vera breytt veðurlag, einkum aukin úrkoma, en einnig dró úr mengun vegna $\mathrm{NO}_{2}$ og $\mathrm{CO}$ með tilkomu hvarfakúta í bílum. ${ }^{4}$ Sterkara malbik á helstu stofnbrautum og aukin gatnaprif hafa einnig stuðlað að pví að draga úr svifryksmengun. Einnig koma auknar kröfur um mengunarvarnir og nýja tækni, sem draga úr pessu álagi. Pá hefur vinnuumhverfi og meðhöndlun hættulegra efna sem geta borist í andrúmsloft gjörbreyst með hertri vinnuverndarlöggjöf og ákvæðum í umhverfislöggjöf. Almenningur er betur að sér en áður um mikilvægi heilnæms andrúmslofts og stjórnvöldum er ljós nauðsyn pess að hafa eftirlit með mengandi starfsemi, vakta loftgæði og tryggja pau með viðeigandi aðgerðum og að upplýsa almenning um pessi málefni. ${ }^{4}$

Loftgæði utandyra hafa verið mæld í Reykjavík síðan 1986. Fyrstu árin var eingöngu mælt svifryk á einni mælistöð sem pá 


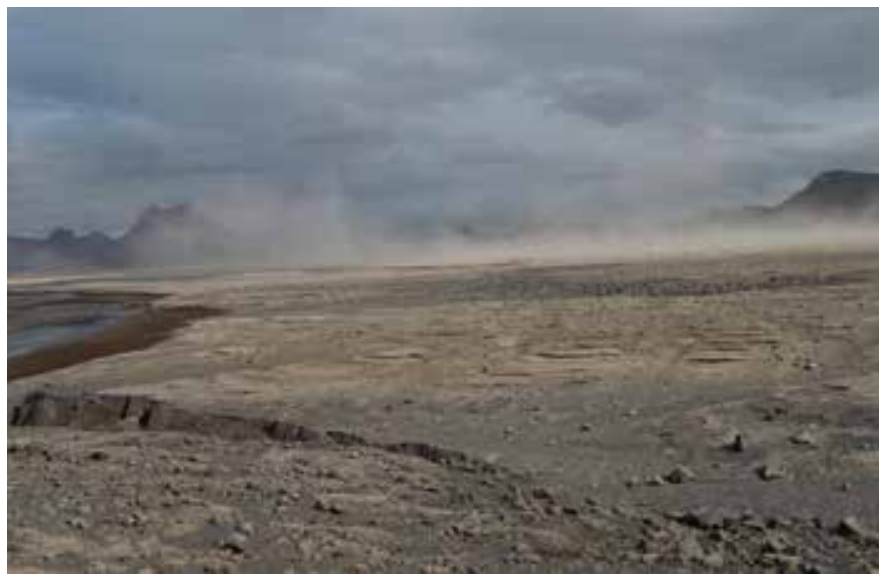

Mynd 1. Jarðvegsfok í nágrenni Hagavatns. Ryk frá pessu svæði og fleiri uppblásturssvæðum berst reglulega yfir péttbýli víða um land. Ljósmynd: Ólafur Arnalds.

var staðsett við Miklatorg. Með árunum hefur fjölgað peim efnum sem mæld eru og bæst hafa við fleiri mælistöðvar. Talsverðar rannsóknir hafa verið gerðar á tengslum loftmengunar við heilsufar Íslendinga og talið er æskilegt að fjölga peim rannsóknum til muna.

\section{Almennt um loftmengun}

Loftmengun utandyra er öll mengun sem finna má í andrúmslofti undir berum himni en hún á sér ýmsar uppsprettur. Efnin eru pví í hærri styrk en ætla mætti miðað við náttúrulegan styrk efnanna. Andrúmsloft utandyra á Íslandi er almennt hreint og lítt mengað, pótt töluverður munur geti verið á péttbýli og dreifbýli og aðstæðum hverju sinni.

Samkvæmt árlegri loftgæðaskýrslu Umhverfisstofnunar Evrópu árið 2018 metur stofnunin út frá styrk loftmengunarefna, lýðfræðilegum upplýsingum og niðurstöðum rannsókna á sambandi milli loftmengunar og heilsufarsbrests að allt að 60 ótímabær dauðsföll megi rekja til útsetningar svifryks á Íslandi á hverju ári. ${ }^{5}$ Einnig eru talin færri en 5 dauðsföll vegna útsetningar á köfnunarefnisdíoxíði og óson. Alpjóðaheilbrigðisstofnunin (World Health Organization, WHO) skilgreinir loftmengun sem eitt helsta umhverfisvandamál nútímans. Samkvæmt mati stofnunarinnar er hægt að rekja allt að 7 milljónir dauðsfalla í heiminum á ári til loftmengunar og talið er að flest peirra orsakist af fínu svifryki. ${ }^{6,7}$ Mikilvægt er koma í veg fyrir og helst að lágmarka loftmengun eins og mögulegt er hér á landi, jafnvel pó svo að hún sé minni hér en í öðrum Evrópuríkjum. ${ }^{5}$

Árið 2010 var sampykkt Parma-yfirlýsingin á fundi ráðherra umhverfis- og heilbrigðismála Alpjóðaheilbrigðistofnunarinnar par sem áhersla er lögð á að vernda heilsu barna gegn skaðlegum umhverfisáhrifum. ${ }^{8}$ Sama ár ákváđu heilbrigðis- og umhverfisráðherrar Íslands að láta safna upplýsingum um loftgæði og meta áhrif loftmengunar á heilsu fólks á Íslandi, einkum barna og ungmenna en börn pola loftmengun verr en fullorðnir og eiga erfiðara með að koma sér undan henni. Einnig má nefna að íslensk stjórnvöld taka mið af Heimsmarkmiðum Sameinuðu pjóðanna um sjálfbæra próun og par eru að minnsta kosti tvö markmið par sem loftgæði koma við sögu. ${ }^{9}$

\section{Hverjir eru helstu pættir loftmengunar á Íslandi?}

Loftmengunarefnin nefnd hér að neðan eru notuð sem umhverfisvísar á gæði andrúmsloftsins. Umhverfisvísir er skilgreindur af Umhverfisstofnun Evrópu sem mælikvarði, venjulega tölulegur, sem hægt er að nota til pess að lýsa og miðla flóknum umhverfisfyrirbærum á einfaldan hátt, par með talið breytingum og próun á ákveðnu tímabili, og hjálpa pannig við að varpa ljósi á ástand umhverfisins..$^{10}$ Eftirfarandi efni eru helstu loftmengunarefni sem mæld eru á Íslandi en til viðbótar má nefna að lykt getur talist til loftmengunar pó hún sé ekki mæld að staðaldri.

- Svifryk ( $\mathbf{P M}_{10}, \mathbf{P M}_{2,5}$ eða $\left.\mathbf{P M}_{1}\right)$ : Svifryk er íslenska pýðingin á enska hugtakinu particulate matter (PM). Pá er átt við alla loftborna mengun sem kemur fyrir sem vökvi eða í föstu formi. Sumt svifryk er smágerðar agnir sem svífa um í andrúmsloftinu og er flokkað eftir stærð agnanna. Pær sem eru minni en $10 \mu \mathrm{m}$ ( $1 \mu \mathrm{m}=1$ míkrómetri = 0,000001 m) í pvermál eru kallaðar $\mathrm{PM}_{10}$. $\mathrm{PM}_{2,5}$ eru agnir minni en 2,5 $\mu \mathrm{m}$ í pvermál og $\mathrm{PM}_{1}$ eru agnir minni en $1 \mu \mathrm{m}$ í pvermál. Örfínt ryk (UFP; ultra-fine particles) er minna en 0,1 $\mu \mathrm{m}$ í pvermál. Til samanburðar má geta pess að mannshár er um $60 \mu \mathrm{m}$ í pvermál. Agnir sem myndast við slit eða núning eru yfirleitt fremur grófar, til dæmis ryk sem myndast við slit á malbiki. Smágerðari agnir verða einna helst til við bruna, til dæmis sót, eða vegna pess að efni péttast, til dæmis brennisteinn, köfnunarefnissambönd og lífræn efni. Svifryk sem er minna en $1 \mu \mathrm{m}$ í pvermál helst svífandi í loftinu og berst með vindstraumum eins auðveldlega og gastegundir.

- Köfnunarefnisoxío ( $\left.\mathrm{NO}_{\mathrm{x}}\right)$ : Köfnunarefnisoxíð $\left(\mathrm{NO}_{\mathrm{x}}\right)$ er samheiti yfir köfnunarefnissamböndin $\mathrm{NO}_{2}$ (köfnunarefnisdíoxíð) og NO (köfnunarefnisoxíð). Köfnunarefnisoxíð getur hvarfast við ósón $\left(\mathrm{O}_{3}\right)$ og breyst úr $\mathrm{NO}$ í $\mathrm{NO}_{2}$ samkvæmt formúlunni: $\mathrm{NO}+\mathrm{O}_{3} \odot \mathrm{NO}_{2}+\mathrm{O}_{2}$.

- Brennisteinsvetni $\left(\mathrm{H}_{2} \mathrm{~S}\right)$ : Litlaus gastegund með lykt sem flestir Íslendingar pekkja sem „,hveralykt“. Gasið er pyngra en andrúmsloft og safnast pví saman við jörðu og í dældum/dölum.

- Brennisteinsdíoxíð $\left(\mathrm{SO}_{2}\right)$ : Gastegund með ramma lykt. Efnið var eitt helsta loftmengunarefnið sem losnaði úr eldgosinu í Holuhrauni árin 2014 til 2015.

- Óson $\left(\mathrm{O}_{3}\right)$ : Ljósblá gastegund sem lyktar líkt og klór. Við yfirborð Íslands er náttúrlegur styrkur $\mathrm{O}_{3}$ lágur samanborið við önnur Evrópuríki. Pað er engin losun af mannavöldum á ósoni heldur er óson svokallað afleitt mengunarefni, pað er pað myndast í andrúmslofti pegar önnur mengunarefni eins og $\mathrm{NO}_{\mathrm{x}}$ og rokgjörn lífræn efnasambönd (volatile organic compounds, VOC) hvarfast saman. Hvarfið gengur hraðar við mikla sólgeislun og háan lofthita. Ósonmengun er pví óveruleg hér á Íslandi en hún er vandamál í heitum sólríkum löndum.

- Kolmónoxíð (CO): Lyktar-, bragð- og litlaus gastegund sem er eitruð par sem hún binst rauðum blóðkornum og hindrar upptöku súrefnis í blóði. 


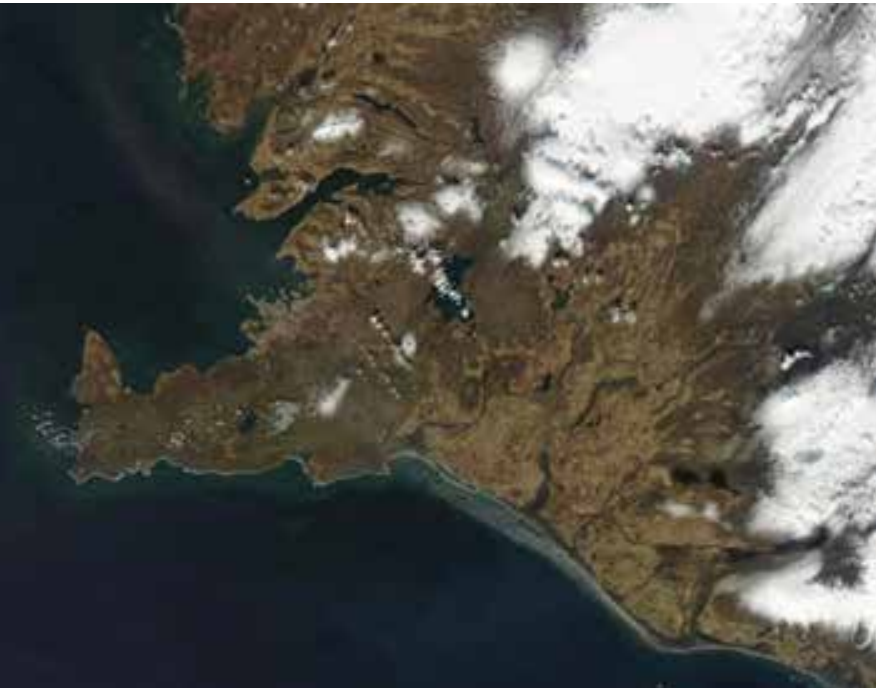

Mynd 2. Loftmynd af sandfoki frá Landeyjasandi tekin 28. apríl 2007. Sjá má rykmökkinn meðfram suðurströndinni allt að Ölfusárósum, paðan yfir Reykjanesskagann, höfuðborgarsvæðið og áfram út á Faxaflóa. Greinilegt mistur var á höfuðborgarsvæðinu pennan dag og hæsta hálftímameðaltal svifryks var $353 \mu \mathrm{g} / \mathrm{m}^{3}$. Mynd: Modis, NASA.

\section{Áhrif loftmengunar á heilsu manna}

Fjöldi rannsókna hafa verið gerðar á áhrifum loftmengunar á heilsu manna og stór hluti peirra hafa sýnt að ákveðnir hópar einstaklinga eru sérstaklega viðkvæmir fyrir loftmengun. Petta eru eldri einstaklingar, pungaðar konur, börn og peir sem pjást af undirliggjandi sjúkdómum. ${ }^{11-14}$ Hér á eftir verður farið betur í áhrif mismunandi loftmengunarefna á heilsu.

\section{Svifryk}

Svifryk getur haft margvísleg áhrif á heilsu manna. Рað hefur verið tengt við aukna tíðni lungnasjúkdóma, krabbameina, hjartaog æðasjúkdóma, sem og heildardánartíðni. ${ }^{11,15-21}$ Aldraðir, börn, og fólk með undirliggjandi öndunarfæra- og hjarta- og æðasjúkdóma eru viðkvæmastir fyrir svifryksmengun.11,13,14,22-24 Áhrifin eru einkum háð stærð agnanna og eru smærri agnir taldar hættulegri heilsu fólks en pær stærri. Stærri agnir en PM $_{10}$ eru síaðar út í nefi og nefholi, en $\mathrm{PM}_{10}$ ná niður í lungnaberkjurnar og allra smæstu agnirnar $\left(\mathrm{PM}_{2.5}\right)$ komast niður í lungnablöðrur og paðan í blóðrásarkerfið. Áhrifanna gætir bæði vegna skammtíma útsetningar (klukkustundir, dagar) og langtíma mengunar (mánuðir, ár). Áhrifin koma fram sem versnandi einkenni sjúkdóma og pannig má sjá aukna tíðni á komum á bráđamóttökur, aukinn fjölda innlagna á sjúkrahús og aukna dánartíðni. ${ }^{25}$ Svifryksmengun getur dregið úr lungnaproska barna. ${ }^{26}$

\section{Brennisteinsvetni $\left(\mathrm{H}_{2} \mathrm{~S}\right)$}

Í miklum styrk er brennisteinsvetni skaðlegt heilsu. ${ }^{3}$ Augu og öndunarfæri eru viðkvæm fyrir áhrifum brennisteinsvetnis. Lægsti styrkur sem talinn er valda skaða er um pað bil 15.000 míkrógrömm í rúmmetra en pað er meira en 100 sinnum yfir peim styrk sem mest hefur mælst hefur í Reykjavík. Rannsóknir á langtíma áhrifum brennisteinsvetnis eru misvísandi. Pannig hafa
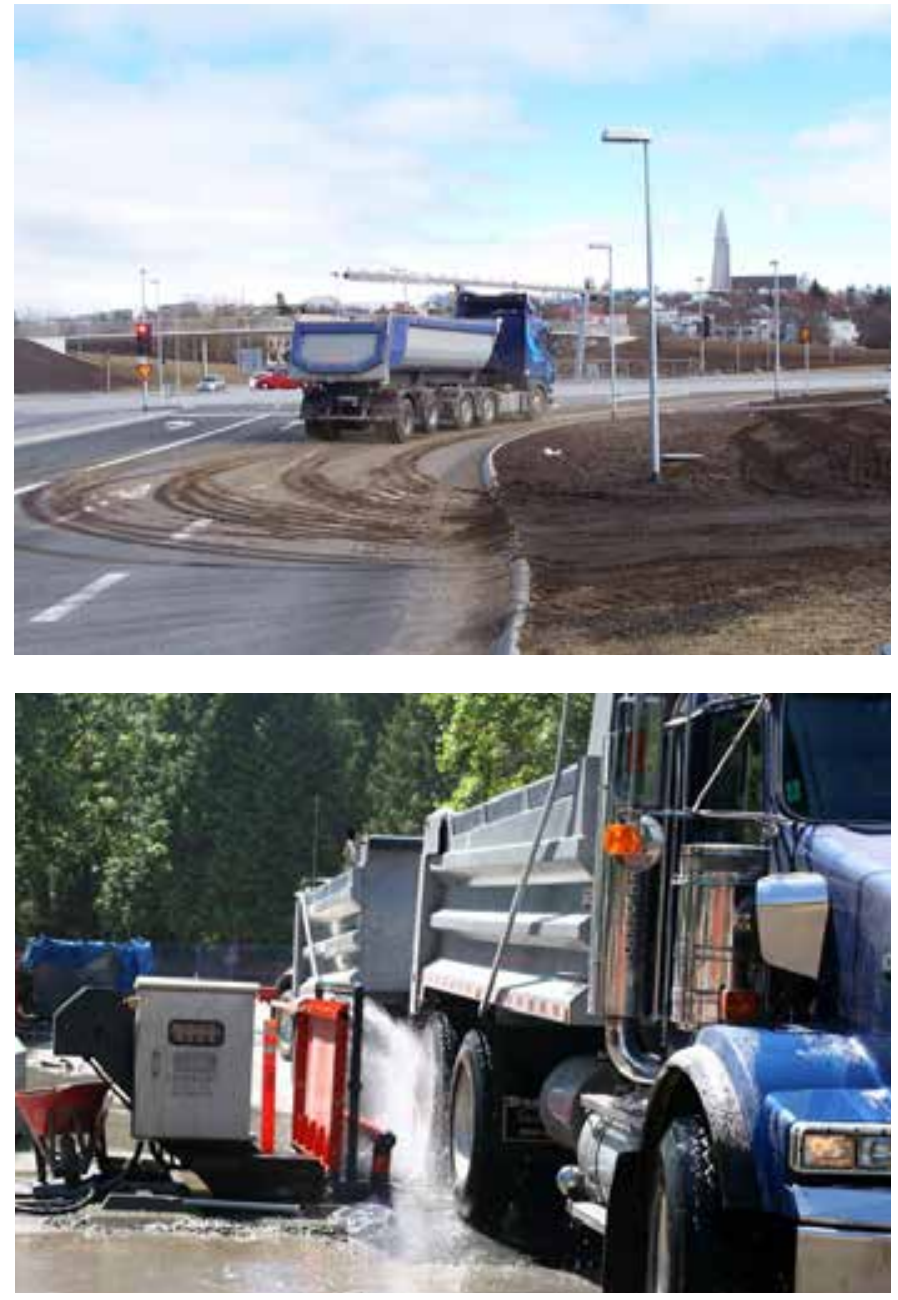

Mynd 3. Moldugar götur við framkvæmdasvæði i Reykjavík og dekkjapvottavél sem kemur í veg fyrir að jarđvegur frá svæðinu berist út í gatnakerfið.

sumar rannsóknir sýnt fram á áhrif á lungnastarfsemi en aðrar hafa ekki sýnt fram á slíkt samband. Pað sama gildir um tengsl við astma og aðra öndunarfærasjúkdóma. ${ }^{27-29}$ Niðurstöður íslenskra rannsókna eru raktar síðar í greininni.

\section{Brennisteinsdíoxíð $\left(\mathrm{SO}_{2}\right)$}

Innöndun á brennisteinsdíoxíði getur stuðlað að astma vegna áhrifa á loftvegi og gert einkenni peirra sem eru með teppusjúkdóma í lungum, eins og astma og langvinna lungnateppu, verri. Svifryksmengun á sama tíma eykur pessi áhrif enn meira. Sjúklingar finna fyrir meiri andpyngslum og mæði og geta purft að leita læknishjálpar ef styrkleiki brennisteinsdíoxíðs í andrúmslofti er mikill. ${ }^{12.25}$ Að auki getur innöndun á $\mathrm{SO}_{2}$ leitt til versnandi einkenna hjarta- og æðasjúkdóma. ${ }^{11,13,14}$

\section{Köfnunarefnisdíoxíð $\left(\mathrm{NO}_{2}\right)$}

Köfnunarefnisdíoxíð er ertandi fyrir öndunarfæri og eykur áhættu á öndunarfærasýkingum. Langtíma útsetning getur stuðlað að astma. ${ }^{30}$ Einnig hafa rannsóknir á áhrifum $\mathrm{NO}_{2}$ sýnt að aukin útsetning efnisins geti leitt til versnandi einkenna hjarta- og 


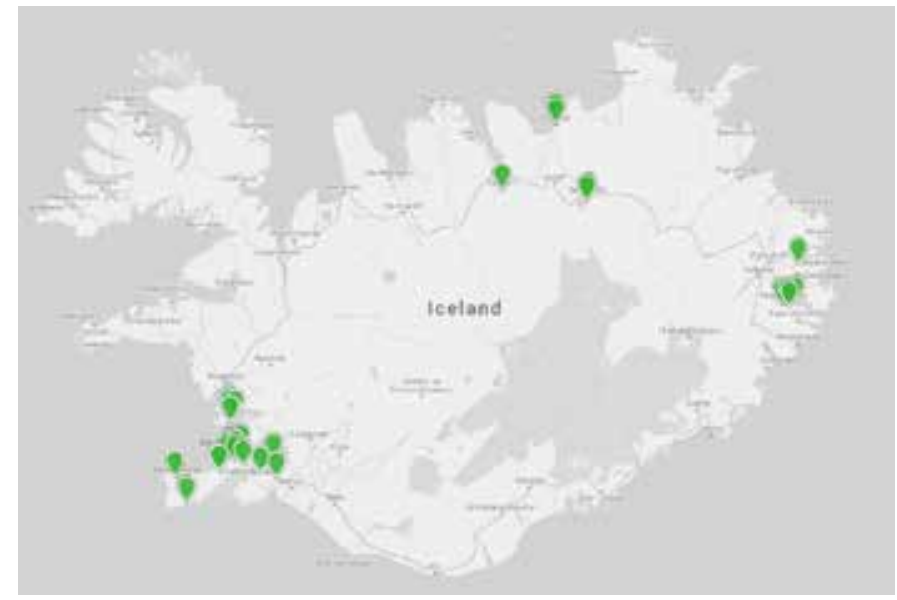

Mynd 4. Íslandskort með staðsetningu loftgæðamælistöðva. Kortin bæði má sjá á slóðinni loftgaedi.is og nýjustu mælingar uppfærast á klukkutíma fresti.

æðasjúkdóma ${ }^{12,14}$ og svifryksmengun á sama tíma eykur pessi áhrif enn meira. Langvarandi útsetning á $\mathrm{NO}_{2}$ hefur verið tengd við hærri dánartíðni vegna heilablóðfalla. ${ }^{11,13}$

Kolmónoxíð (CO)

Innöndun kolmónoxíðs veldur truflun á bindingu súrefnis við blóðrauða og par með öndun frumna. Petta getur minnkað súrefnisflutning til hjartans og verið skaðlegt fyrir sjúklinga með kransæðasjúkdóma. Ekki hafa fundist tengsl við gáttatif. ${ }^{31}$

Óson

Óson er litarlaus lofttegund sem hefur áhrif á öndunarfæri. Útsetning fyrir óson hefur verið tengd við astma, berkjubólgu, hjarta- og æðasjúkdóma og einnig ótímabær dauðsföll. 25,32

\section{Uppsprettur loftmengunar}

Í töflu I má sjá uppruna helstu mengunarvalda andrúmslofts á Íslandi. Sum pessara efna eru í lágum styrk í andrúmsloftinu, eða koma frá náttúrulegum uppsprettum, en önnur efni eiga rætur sínar að rekja til mannlegra athafna. Helsta uppspretta loftmengunar í péttbýli eru samgöngur. Við bruna jarðefnaeldsneytis, til dæmis

Tafla I. Uppruni helstu loftmengunarefna sem mæld eru á Íslandi ásamt veðurfarsaðstæðum sem ýta undir hærri styrk efnanna.

\begin{tabular}{l|l}
\hline Loftmengunarefni & Uppruni \\
\hline $\begin{array}{l}\text { Brennisteinsdíoxíð } \\
\mathrm{SO}_{2}\end{array}$ & Iðnaður, útblástur bíla og skipa og eldgos \\
\hline Brennisteinsvetni $\mathrm{H}_{2} \mathrm{~S}$ & $\begin{array}{l}\text { Jarðvarmavirkjanir, náttúruleg útgufun á } \\
\text { hverasvæðum }\end{array}$ \\
\hline Köfnunarefnisoxíð $\mathrm{NO}_{x}$ & Útblástur bíla, skipa og annarra véla \\
\hline Kolmónoxíð CO & Útblástur bíla og stóriðja \\
\hline Óson $\mathrm{O}_{3}$ & $\begin{array}{l}\text { Náttúrlegur styrkur við yfirborð jarðar og } \mathrm{O}_{3} \text { sem } \\
\text { hefur borist langar leiðir frá öðrum löndum }\end{array}$ \\
\hline Svifryk & $\begin{array}{l}\text { Slit gatna, útblástur bíla, byggingarframkvæmdir, } \\
\text { flugeldar, brennur, gróðureldar, selta, uppblástur/ } \\
\text { sandfok og eldgos (öskufall/öskufok) }\end{array}$ \\
\hline Lykt & $\begin{array}{l}\text { Fjölbreyttar uppsprettur, til dæmis iðnaður, jarðhiti og } \\
\text { jarðvarmavirkjanir, fiskpurrkun, húsdýraáburður á tún }\end{array}$ \\
\hline
\end{tabular}

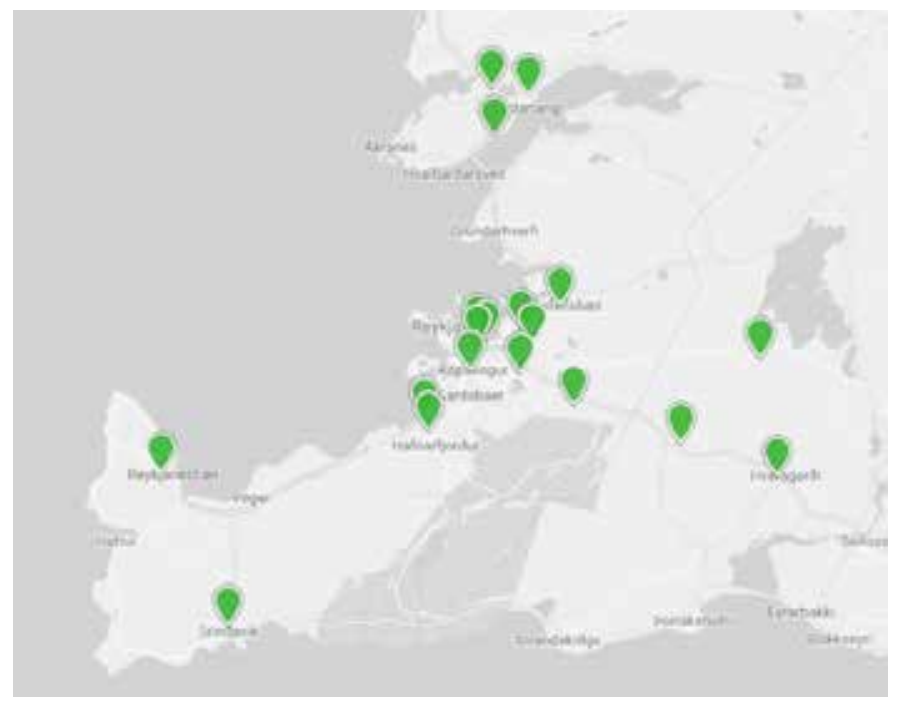

Mynd 5. Kort af suðvesturhorni Íslands sem sýnir nánar staðsetningu loftgæðamælistöðva í mars 2019

bensíns og dísilolíu, myndast fjöldi loftmengunarefna á borð við $\mathrm{NO}, \mathrm{CO}$ og $\mathrm{SO}_{2}$. Einnig myndast örfínt svifryk $\left(\mathrm{PM}_{2,5}\right.$ og minna) auk grófari agna $\left(\mathrm{PM}_{10} \mathrm{og}\right.$ stærra). Fínustu agnirnar eru sótagnir. Við slit eða núning gatna myndast fremur grófar agnir sem safnast mikið saman á götur og við vegbrúnir. Aðrar uppsprettur eru náttúrulegar, svo sem eldgos, jarðvegsrof og uppgufun frá hverasvæðum. Eldgos hafa verið ein helsta uppspretta svifryks og $\mathrm{SO}_{2}$ síðustu ár en helsta efnið sem losnar á hverasvæðum og frá jarðvarmavirkjunum er $\mathrm{H}_{2} \mathrm{~S}$. Að auki getur styrkur loftmengandi efna hér á landi hækkað tímabundið vegna loftmengunarefna sem berast langar leiðir, svo sem frá Evrópu eða Bandaríkjunum.

\section{Náttúrulegar uppsprettur}

Jarðvegsfok

Á Íslandi eru stærstu eyðimerkursvæði í Evrópu og jarðvegsfok frá peim svæðum er ein af uppsprettum loftmengunar á Íslandi. Alls eru rúmlega 20\% landsins skilgreind sem eyðimerkursvæði. Stóran hluta sandfoks má pó rekja til afmarkaðra svæða, svokallaðra strókasvæða. Virkustu strókasvæðin eru Dyngjusandur, umhverfi Hagavatns (sjá mynd 1), Landeyjasandur og Skeiðarársandur. ${ }^{33}$ Fólk sem býr nálægt pessum svæðum er meira útsett fyrir svifryksmengun af völdum jarðvegsfoks en fólk sem býr á höfuðborgarsvæðinu. Jarðvegsfok frá pessum svæðum getur pó við ákveðnar veðuraðstæður borist langar leiðir. Рað gerist til dæmis reglulega að sandfok frá Landeyjasandi berist yfir höfuðborgarsvæðið. Dæmi um pað má sjá á mynd 2.

Eldgos

Eldgos valda loftmengun með gjóskufalli og útstreymi kvikugasa. ${ }^{3}$ Gjóska er samheiti á lausum gosefnum sem berast frá gosopi í lofti. Eitt peirra er aska sem er efni smærra en $2 \mathrm{~mm}$. Bráð áhrif ösku á heilsufar manna eru vel pekkt. Gosaska getur valdið einkennum frá efri öndunarfærum eins og nefrennsli og ertingu í nefi. Pá koma einnig fram særindi í hálsi og hósti. Peir sem eru með 
lungnasjúkdóma eins og astma eða langvinna lungnateppu geta fengið versnandi einkenni með hósta, uppgangi, öndunarerfiðleikum og pyngslum fyrir brjósti. Ef kornastærð ösku er $4 \mu \mathrm{m}$ eða minni getur hún borist í lungnablöðrur. Í augum geta komið fram særindi, kláði og roði. Einnig getur orðið tárarennsli og pað geta komið fram sár á hornhimnu. Рað geta einnig komið fram erting, sviði, roði og kláði í húð. Lítið er enn vitað um langtíma áhrif gosösku á heilsufar manna. Mjög erfitt er að rannsaka pessi áhrif vegna pess að önnur loftmengun er einnig til staðar. Ekki eru til neinar rannsóknir á langtíma áhrifum á Íslandi. ${ }^{3}$

Margvíslegar lofttegundir geta komið upp í eldgosum. Áhrifum lofttegunda má skipta í tvennt. Í fyrsta lagi lofttegundir sem eru ertandi fyrir slímhúðir og húð. Í lágum styrkleika valda pær ertingu í augum og efri hluta öndunarfæra. Í hærri styrk valda pær ertingu og bruna í húð og í enn hærri styrk hafa pær áhrif á neðri hluta öndunarfæra og geta valdið lungnabjúg vegna bráðs lungnaskaða. Dæmi um pað er brennisteinsdíoxíð og brennisteinssýra. Í öðru lagi eru lofttegundir sem valda köfnun vegna áhrifa á flutning súrefnis og öndunarkeðjuna í frumum. Dæmi um pað er kolmónoxíð.

\section{Losun af mannavöldum}

\section{Saga loftmengunar}

Í huga margra er loftmengun eitthvað sem kom til með iðnbyltingunni. En raunin er sú að loftmengun af manna völdum á sér mun lengri sögu. Leiða má líkur að pví að fyrstu áhrif loftmengunar á heilsu fólks hafi komið fram á steinöld pegar maðurinn lærði að nýta sér opinn eld til matreiðslu. Elstu rituðu heimildir um loftmengun eru frá tíma Rómaveldis par sem lýst er illa pefjandi og fúlu lofti í rómverskum borgum. Líklegt má telja að par hafi sorp, skólp og notkun elds við matargerð átt hlut að máli. Saga loftmengunar er talsvert tengd sögu London. Elstu heimildir um pað sem kalla mætti kvartanir vegna loftmengunar eru frá London og eru frá árinu 852. Hugtakið loftmengun var reyndar ekki til pá en talað er um fúlt loft vegna bruna kola til húshitunar. Fyrstu lög sem tengdust loftmengun voru sett í London á 12. öld en pá sampykkti enska pingið lög sem bönnuðu ákveðna gerð af kolum. Fyrsta ritið sem kalla má fræðirit um loftmengun var skrifað af enska fræðimanninum John Evelyn og kom pað út árið 1661 og fjallaði um loftmengun í London. Par fjallar hann meðal annars um möguleg áhrif reyks í London á heilsu íbúanna og kemur með tillögur til að draga úr reyknum sem lá iðulega yfir borginni. ${ }^{34}$ Í nútímasögu loftmengunar má segja að alger páttaskil hafi orðið í viðhorfi almennings og stjórnvalda eftir nokkra mjög slæma mengunardaga í London í byrjun desember 1952. Talið er að um 6000 manns hafi látist í borginni vegna loftmengunar pessa daga og varð pessi atburður til pess að stórauka rannsóknir á mögulegum áhrifum loftmengunar á heilsu fólks. ${ }^{35}$

\section{Losun á Íslandi af mannavöldum}

Eins og sjá má í töflu I eru uppsprettur loftmengunar mismunandi. Á Íslandi er pað loftmengun frá bílaumferð sem helst hefur áhrif á heilsu fólks. Losun frá bílum á sér almennt stað mjög nálægt heimilum, skólum og öðrum stöðum par sem fólk dvelur.
Tafla II. Heilsuverndarmörk loftmengunarefna samkvæmt íslenskum reglugerðum.

\begin{tabular}{llll}
$\begin{array}{l}\text { Loft- } \\
\text { mengunar- } \\
\text { efni }\end{array}$ & $\begin{array}{l}\text { Tími } \\
\text { mælinga }\end{array}$ & $\begin{array}{l}\text { Heilsu- } \\
\text { verndarmörk }\end{array}$ & $\begin{array}{l}\text { Leyfilegur fjöldi } \\
\text { skipta yfir mörkum } \\
\text { ár hvert* }\end{array}$ \\
\hline $\mathrm{PM}_{10}$ & Sólarhringsmeðaltal & $50 \mu \mathrm{g} / \mathrm{m}^{3}$ & 35 \\
\hline $\mathrm{PM}_{10}$ & Ársmeðaltal & $40 \mu \mathrm{g} / \mathrm{m}^{3}$ & - \\
\hline $\mathrm{PM}_{2,5}$ & Ársmeðaltal & $20 \mu \mathrm{g} / \mathrm{m}^{3}$ & - \\
\hline $\mathrm{NO}_{2}$ & Klukkustundarmeðaltal & $200 \mu \mathrm{g} / \mathrm{m}^{3}$ & 18 \\
\hline $\mathrm{NO}_{2}$ & Sólarhringsmeðaltal & $75 \mu \mathrm{g} / \mathrm{m}^{3}$ & 7 \\
\hline $\mathrm{NO}_{2}$ & Ársmeðaltal & $40 \mu \mathrm{g} / \mathrm{m}^{3}$ & - \\
\hline $\mathrm{O}_{3}$ & Hæsta 8-klst. & $120 \mu \mathrm{g} / \mathrm{m}^{3}$ & 0 \\
\hline $\mathrm{SO}_{2}$ & hlaupandi meðaltal & & 24 \\
\hline $\mathrm{SO}_{2}$ & Klukkustundarmeðaltal & $350 \mu \mathrm{g} / \mathrm{m}^{3}$ & 3 \\
\hline $\mathrm{H}_{2} \mathrm{~S}$ & Sólarhringsmeðaltal & $125 \mu \mathrm{g} / \mathrm{m}^{3}$ & 3 \\
\hline $\mathrm{H}_{2} \mathrm{~S}$ & Hlaupandi 24-klst. & $50 \mu \mathrm{g} / \mathrm{m}^{3}$ & - \\
\hline & meðaltal & $5 \mu \mathrm{g} / \mathrm{m}^{3}$ & \\
\hline $\mathrm{A}^{3}$ & & & 2 \\
\hline
\end{tabular}

*Á ekki viơ um ársmeðaltal.

Helstu mengunarefni frá umferð eru svifryk og nituroxíð. Stór hluti svifryks frá umferð kemur frá vegyfirborðinu og par er slit nagladekkja á slitlagi ráðandi páttur. Á Íslandi eru einnig aðrar stórar mengunaruppsprettur, svo sem fiskiskip, flugvélar og stóriðja. Pótt losun loftmengunarefna frá pessari starfsemi geti verið umtalsverð er losunin allajafna fjær mannabústöðum og áhrifin á heilsu fólks pví minni en frá bílaumferð. Í næsta nágrenni stórra hafna getur pó verið allnokkur loftmengun. Eitt af pví sem gagnast til að draga úr loftmengun í nágrenni hafna er að koma á landtengingu rafmagns við skip í höfn til að lágmarka mengun frá keyrslu ljósavéla.

Helsta mengunarefnið frá stóriðju er brennisteinsdíoxíð. Fimm stóriðjusvæði eru á landinu og er brennisteinsdíoxíðmengun að mestu bundin við svæðin nálægt iðjuverum. Gera má ráð fyrir að svæði par brennisteinsdíoxíðs gætir að einhverju ráði sé í nokkurra kílómetra radíus umhverfis iðjuverin. Ekki endilega hringlaga heldur aflöng í takt við ríkjandi vindáttir á hverjum stað.

Talsverð losun brennisteinsvetnis er frá jarðvarmavirkjunum á Íslandi. Mengun frá Nesjavallavirkjun og Hellisheiðarvirkjun mælist reglulega á mælistöðvum á höfuðborgarsvæðinu og í Hveragerði. Brennisteinsvetni hefur tærandi áhrif á raftæki og mannvirki úr málmi.

Frá byggingarsvæðum getur verið talsverð loftmengun, bæði frá útblæstri vinnuvéla en ekki síður frá ryki sem pyrlast upp við framkvæmdirnar. Petta getur valdið umtalsverðri rykmengun í næsta nágrenni. Petta getur til dæmis verið steypuryk frá niðurbroti bygginga en hægt er að lágmarka pað með pví að sprauta vatni á pá byggingarhluta sem verið er að rífa hverju sinni. Einnig getur verið talsverð rykmengun frá óhreinindum sem berast með vörubíladekkjum út í almenna gatnakerfið. Dæmi eru um að götur í péttbýli sé moldugar mörg hundruð metra út frá framkvæmdasvæði og svifryksmengun frá pessu jarðvegsryki pví talsverð í nágrenninu. Dæmi um mótvægisaðgerðir sem hægt er að grípa til er að nota sérstakar dekkjapvottavélar fyrir vörubílana ádur en peir 


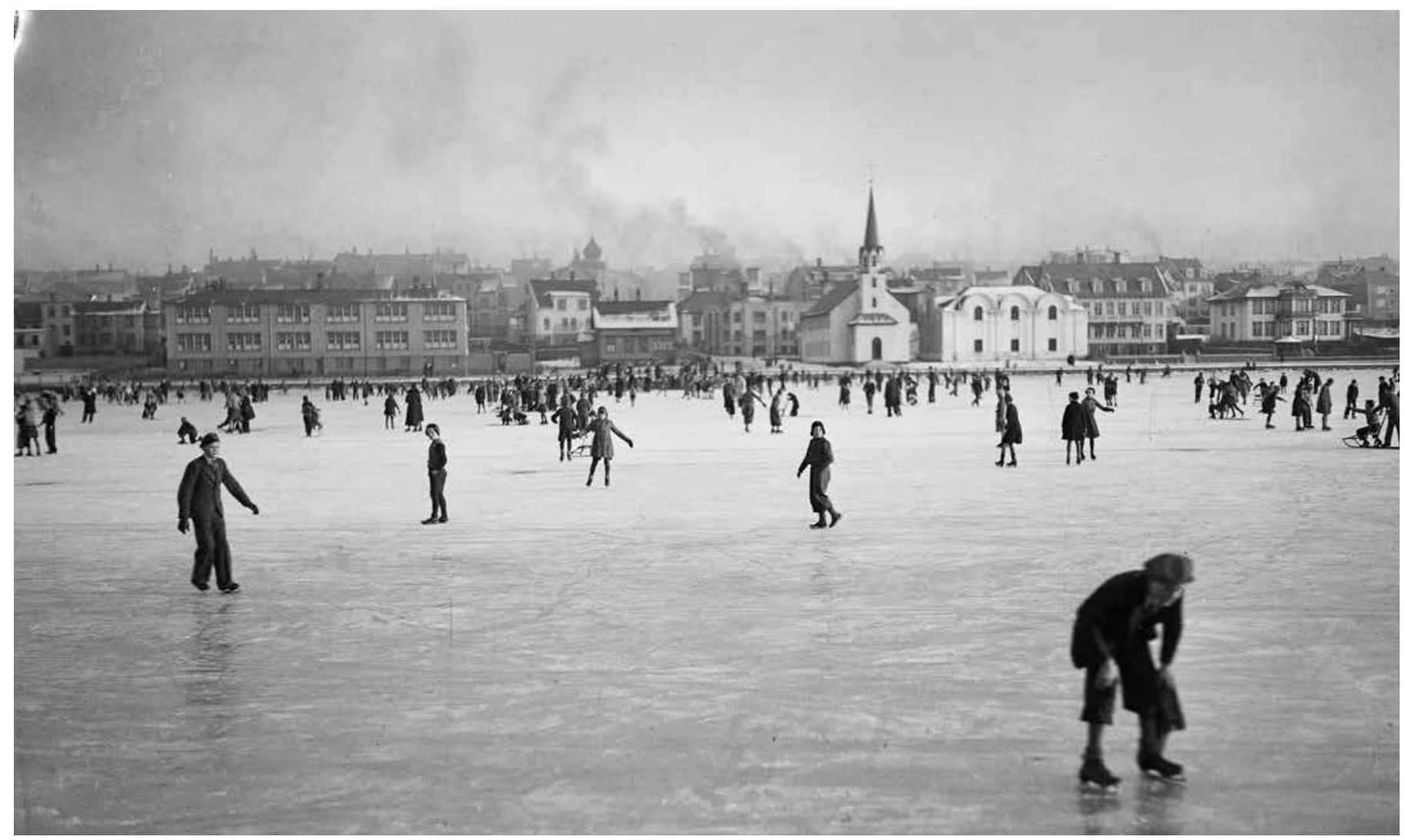

Mynd 6. Kolareykur yfir Pingholtunum í Reykjavík á fyrri hluta 20. aldar. Mynd: Sigurhans Vignir. Ljósmyndasafn Reykjavíkur.

aka út af framkvæmdasvæðinu. Petta hefur verið mjög lítið notað hér á landi en full ástæða er að gera petta par sem eru stórar framkvæmdir inni í eldri hverfum. Dæmi um petta má sjá á mynd 3.

\section{Mælingar á loftmengun á Íslandi}

Mælingar á loftmengun á Íslandi hófust árið 1968 í nágrenni álversins í Straumsvík. Pað var hins vegar ekki fyrr en árið 1986 sem mælingar hófust á loftmengun frá bílaumferð pegar sett var upp mælistöð við Miklatorg í Reykjavík. Áður en pær mælingar hófust var pað trú margra að loftmengun væri bara eitthvað sem væri í útlöndum. Fyrstu niðurstöður mælinga við Miklatorg sýndu hins vegar að pað gátu komið dagar par sem svifryksmengun var umtalsverð. Mælingar við Miklatorg opnuðu augu yfirvalda fyrir mikilvægi pess að safna frekari upplýsingum og árið 1990 var gangsett í Reykjavík fyrsta sjálfvirka loftgæðamælistöðin.

Vöktun á loftgæðum hér á landi hefur eflst á undanförnum árum og bæði mælistöðum og peim efnum sem mæld eru hefur fjölgað. Heildarfjöldi mælistöðva á Íslandi í upphafi árs 2017 var 36 alls og staðsetningu peirra má sjá á mynd 4 og mynd 5. Staðsetning tækjanna ræðst af uppsprettum mengunar.

Í lok árs 2017 gaf umhverfis- og auðlindaráðuneyti út „Áæetlun um loftgæði á Íslandi 2018-2019 - Hreint loft til framtíðar“. Í áætluninni eru sett fram prjú markmið með röð aðgerða til að stuðla аð loftgæðum og heilnæmu umhverfi í landinu. Ein af mörgum aðgerðum með aðkomu Umhverfisstofnunar er að stofnunin komi á laggirnar loftgæðaupplýsingakerfi til að tryggja aðgengi almennings og haghafa að upplýsingum um loftgæði í landinu. ${ }^{4}$ petta á að auðvelda mat á loftgæðum á Íslandi. Umhverfisstofn- un hefur nú pegar innleitt alhliða loftgæðaupplýsingakerfi sem ber heitið Airviro. Petta yfirgripsmikla kerfi er notað til að vinna með gögn í formi tímaraða (loftmengunarmælingar) og auðvelda skráningu á uppsprettum loftmengandi efna og gerð loftdreifilíkana. Að auki mun pað geta starfað sem alhliða gagnagrunnur um losun loftmengandi efna í landinu og pví verður aðgengi, notkun og miðlun gagnanna auðveldari og einnig er hægt að spá fyrir um styrk efnanna að minnsta kosti tvo daga fram í tímann með kerfinu. Airviro býður upp á ótal möguleika í notkun og miðlun loftgæðagagna, svo sem að auðvelda rekstur og eftirlit með loftgæðamælistöðvum í landinu og senda viðeigandi aðilum upplýsingar, til dæmis ef stöð verður rafmagnslaus eða bilar. Einnig auðveldar раð eftirfylgni með pví hvort loftmengunarefni fara yfir tilskilin mörk ásamt pví að streyma nær-rauntíma gögnum um loftgæði á landinu á loftgæðavef Umhverfisstofnunar (loftgaedi.is). Í íslenskum reglugerðum eru sett heilsuverndarmörk fyrir skilgreind loftmengunarefni ásamt pví að settar eru fram samræmdar leiðbeiningar um mælingar á styrk peirra. Heilsuverndarmörk eru hugsuð fyrir almenning, bæði börn og fullorðna, sjúka sem heilbrigða og er peim ætlað að vera viðmiðun fyrir hvað telst skaðlaust fyrir einstaklinga og pau eru sett til að tryggja heilsu manna til lengri tíma.

Tilgreind mörk reglugerða um loftgæði á Íslandi, að undanskilinni reglugerð um styrk $\mathrm{H}_{2} \mathrm{~S}$ í andrúmslofti, eru í samræmi við mörk Evrópureglugerða. ${ }^{36,37}$ Hins vegar er ekki til samræmd löggjöf fyrir styrk $\mathrm{H}_{2} \mathrm{~S}$ í andrúmslofti á Evrópska efnahagssvæðinu. Alpjóðaheilbrigðisstofnunin leggur til að heilsuverndarmörk fyrir $\mathrm{H}_{2} \mathrm{~S}$ séu $150 \mu \mathrm{g} / \mathrm{m}^{3}$ og árið 2010 voru íslensk heilsuverndarmörk skilgreind sem $50 \mu \mathrm{g} / \mathrm{m}^{3}$. Í töflu II má sjá íslensk heilsuverndar- 
mörk fyrir helstu loftmengunarefni sem eru mæld á Íslandi samkvæmt framangreindum reglugerðum.

\section{próun loftgæða á Íslandi}

Pó mælingar á loftmengun hafi ekki hafist á Íslandi fyrr en 1968 má ráða af ýmsum heimildum að landsmenn hafi lengi búið við loftmengun sem hafi haft neikvæð áhrif á heilsu peirra. Gegnum aldirnar hefur pað fyrst og fremst verið slæmt inniloft sem hafði áhrif og pá sérstaklega eldamennska yfir opnum eldi á hlóðum. Með aukinni péttbýlismyndum fór loftmengunar að gæta utan dyra og framan af 20. öldinni voru flest hús í Reykjavík hituð upp með kolum. Sjá má á ljósmyndum frá peim tíma að á góðviðrisdögum að vetri til lá iðulega svartur kolareykur yfir borginni (mynd 6). Upp úr 1970 var hitaveitan búin að leysa jarðefnaeldsneyti af hólmi við húshitun. Frá upphafi bílaaldar á Íslandi hefur loftmengun fylgt bílum. Fjöldi bíla er ráđandi páttur um magn mengunar en aðrir pættir hafa líka áhrif. Langt fram eftir 20. öldinni var staðan pannig í Reykjavík að malbikaðar götur voru að mestu bundnar við miðbæinn en götur úthverfa á hverjum tíma voru malargötur, oft áratugum saman. •að var ekki fyrr en á 6. og 7. áratugnum sem götur voru almennt malbikaðar. Áður en götur voru almennt malbikaðar hefur nokkuð örugglega verið mjög mikið göturyk í lofti en hins vegar eru engar mælingar til frá pessum tíma.

Reglur um mengunarvarnarbúnað í bílum og reglur um efnainnihald eldsneytis hafa líka haft mikil áhrif til að draga úr loftmengun og áhrifum hennar á fólk. Fyrstu hvarfakútar komu í bíla um miðjan 8. áratug síðustu aldar og síðan hefur próun peirra haldið áfram í takt við strangari reglugerðir. Nýir bílar losa margfalt minna af mengunarefnum eins og kolmónoxíði og nituroxíði en eldri bílar. Pessi próun hefur skilað sér í betri loftgæðum. Pannig er til dæmis mun minni kolmónoxíðmengun í Reykjavík í dag en var fyrir 25 árum, prátt fyrir mikla fjölgun bíla. Reglur um efnainnihald eldsneytis hafa líka mikil áhrif á loftmengun. Áður fyrr var blýi bætt út í bensín til að fá fram ákveðna eiginleika pess. Notkun bensíns með íbættu blýi var bönnuð á Íslandi fyrir um 30 árum og áhrifin af pví banni voru mjög greinileg. Styrkur blýs í andrúmslofti minnkaði mikið en hæstu mánaðarmeðaltöl 1991 voru um 1/10 af pví sem pau voru árið 1987. Petta skilaði sér beint í minni styrk blýs í blóði fólks í Reykjavík. Gerðar voru mælingar á blýinnihaldi í blóði fólks Reykjavík árin 1975-1976 og svo aftur á árunum 1991-1992. Niðurstaðan var að blý í blóði fólks í seinni rannsókninni var á bilinu $1 / 5$ til $1 / 3$ af pví sem pað var í fyrri rannsókninni en minnkunin var mismikil eftir pví við hvað fólk starfaði. ${ }^{38}$

Nú er staðan pannig að ef loftmengun fer yfir heilsuverndarmörk í péttbýli á Íslandi er pað oftast vegna svifryksmengunar frá vegyfirborði. ${ }^{39}$ Sem dæmi má nefna að árið 2018 fór svifryksmengun á mælistöðinni við Grensásveg 18 sinnum yfir heilsuverndarmörk, par af voru 17 skipti vegna mengunar frá umferð par sem ryk frá vegyfirborði er stærsti hlutinn. ${ }^{40}$ раð gerist oftast seinni hluta vetrar og að vori til og er orsökin að stórum hluta slit á malbiki vegna mikillar notkunar nagladekkja. En prátt fyrir pessa háu svifrykstoppa eru loftgæði á Íslandi pau bestu í Evrópu. Árlega tekur Umhverfisstofnun Evrópu saman skýrslu um loftgæði í öllum löndum Evrópska efnahagssvæðisins. Mörg undanfarin ár hefur Ísland verið í besta sæti og hér eru færri ótímabær dauðsföll af völdum loftmengunar heldur en í nokkru öðru landi í Evrópu. Í nýjustu skýrslunni sem kom út árið 2018 eru töpuð æviár á hverja 100.000 íbúa borin saman milli landa. Á Íslandi voru 204 töpuð æviár á hverja 100.000 íbúa, Noregur kom næst á eftir með 250 töpuð æviár en Búlgaría rak lestina með 1972 töpuð æviár á hverja 100.000 íbúa. $^{5}$

Á mynd 7 má sjá ársmeðaltalsstyrk $\mathrm{H}_{2} \mathrm{~S}, \mathrm{NO}_{2}, \mathrm{PM}_{10}$ og $\mathrm{SO}_{2}$ á höfuðborgarsvæðinu og á Akureyri, frá 5 mælistöðvum. Heilsuverndarmörk fyrir PM $_{10}$ (tafla II) er $50 \mu \mathrm{g} / \mathrm{m}^{3}$ frá árinu 2016 en fram að pví voru mörkin $20 \mu \mathrm{g} / \mathrm{m}^{3}$. Styrkur efnisins fór hvergi yfir heilsuverndarmörkin fyrir árið 2016 en fram að pví gerðist pað bæði í Reykjavík og á Akureyri að styrkurinn fór yfir $20 \mu \mathrm{g} / \mathrm{m}^{3}$. Hæstu svifryksgildi eru almennt að mælast á Akureyri en pað er einkum vegna pess að á pví svæði er sandur mikið notaður til hálkuvarnar og hátt hlutfall bíla keyrir um á nagladekkjum. En einnig má nefna að veðuraðstæður á borð við tíðar vindstillur og staðsetning bæjarins inni í pröngum firði ýta undir hærri styrk loftmengunarefna vegna lítillar blöndunar andrúmsloftsins. Svifryk er almennt lægra í úthverfum á borð við Dalsmára í Kópavogi og Hafnarfirði en par hefur bílaumferð ekki eins mikil áhrif. Styrkur $\mathrm{NO}_{2}$ og $\mathrm{SO}_{2}$ er almennt lágur og undir heilsuverndarmörkum (tafla II) en árið 2014 var mikil losun $\mathrm{SO}_{2}$ frá eldgosinu í Holuhrauni sem leiddi til pess að pað varð gríðarleg hækkun í ársmeðaltali efnisins. Heilsuverndarmörk fyrir árlegan styrk $\mathrm{H}_{2} \mathrm{~S}$ er $5 \mu \mathrm{g} / \mathrm{m}^{3}$ (tafla II) og hefur styrkur efnisins verið undir peim mörkum á pessum svæðum frá pví að mælingar hófust.

\section{Íslenskar rannsóknir á áhrifum loftmengunar á heilsu}

Rannsóknir á loftmengun og heilsufari Reykvíkinga

Tvær íslenskar rannsóknir hafa verið gerðar á sambandinu milli loftmengunar og notkunar lyfja. Fyrri rannsóknin er frá árinu 2012 og fann samband milli loftmengunar í Reykjavík og úttekta lyfja við astma. ${ }^{41}$ Pegar priggja daga meðaltal svifryks og $\mathrm{H}_{2} \mathrm{~S}$ jókst í Reykjavík jukust astmalyfjaúttektir um 1\% og 2\% 3-5 dögum eftir að aukningin í loftmengun átti sér stað. Í seinni rannsókninni kom fram að úttektir lyfja við hjartaöng jukust í kjölfar hækkunar á $\mathrm{NO}_{2}$ og $\mathrm{O}_{3}$ í Reykjavík en sjá mátti $14 \%$ og $9 \%$ hækkun í hjartalyfjaúttektum sama dag og loftmengun jókst. ${ }^{42}$ Daginn eftir var hækkunin í hjartalyfjaúttektum $10 \%$ og 9\% í kjölfar hækkunar á $\mathrm{NO}_{2}$ og $\mathrm{O}_{3}$. Að auki hefur sambandið milli $\mathrm{H}_{2} \mathrm{~S}$ í Reykjavík og heilsufars verið rannsakað í tveimur öðrum rannsóknum frá árunum 2014 og 2016 en á höfuðborgarsvæðinu má rekja $\mathrm{H}_{2} \mathrm{~S}$ til jarðvarmavirkjana í nágrenni borgarinnar. ${ }^{43,44}$ Fyrri rannsóknin leiddi í ljós samband milli $\mathrm{H}_{2} \mathrm{~S}$ mengunar í Reykjavík og dauðsfalla meðal íbúa höfuðborgarsvæðisins. Pegar 24 klukkustunda styrkur $\mathrm{H}_{2} \mathrm{~S}$ jókst á höfuðborgarsvæðinu mátti greina aukningu í dauðsföllum einum og tveimur dögum seinna upp að rúmum $5 \%$ yfir sumarmánuðina (maí til október). Einnig mátti sjá að sambandið var sterkara meðal karlmanna og eldri einstaklinga (80 ára og eldri). Ekki fannst samband milli annarrar umferðartengdrar loftmengunar og dauðsfalla í pessari rannsókn. ${ }^{44}$

Seinni rannsóknin sýndi fram á samband milli $\mathrm{H}_{2} \mathrm{~S}$ í Reykjavík og koma og innlagna á Landspítala vegna hjarta- og æðasjúkdóma. Rannsóknin sýndi að pegar 24 klukkustunda styrkur 


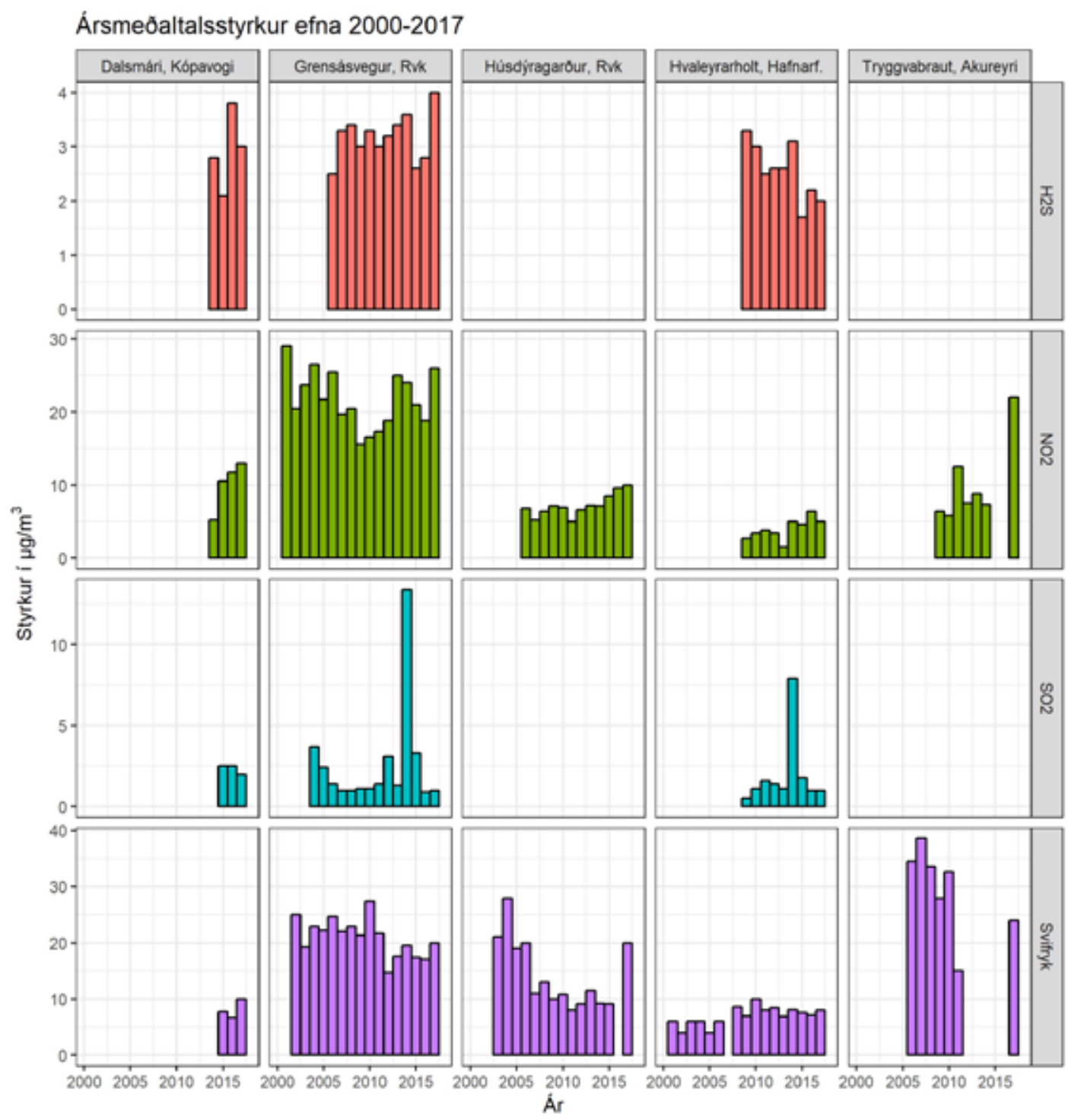

Mynd 7. Ársmeðaltalsstyrkur brennisteinsvetnis, brennisteinsdíoxíðs, köfnunarefnisdíoxíðs og svifryks á 5 stöðum á Íslandi árin 2000-2017.

leið niður í lungnablöðrur (stærð undir $10 \mu \mathrm{m}$ ). Pau rannsökuðu íbúa á svæðinu, alls 207 manns, í byrjun júní 2010. Tæplega helmingur hópsins hafði fundið fyrir áreiti í efri hluta öndunarfæra eftir að hafa verið útsettur fyrir ösku og fjórðungur í augum. ${ }^{46}$ Hin rannsókn Hanne Krage Carlsen og félaga gekk út á að kanna hvort pað að upplifa að vera nálægt eldgosi stuðlaði að aukinni tíðni líkamlegra eða geðrænna einkenna. ${ }^{47}$ Til að kanna petta svöruðu Sunn-

$\mathrm{H}_{2} \mathrm{~S}$ fór yfir lyktarmörkin $\left(7 \mu \mathrm{g} / \mathrm{m}^{3}\right)$ í Reykjavík fjölgaði innlögnum allt að fjórum dögum seinna um allt að $5 \%$. Pegar sambandið var skoðað nánar kom í ljós að karlmenn voru viðkvæmari en konur og eldra fólk viðkvæmara en peir yngri (72 ára og yngri). ${ }^{43}$ Báðar pessar rannsóknir finna sterkt samband milli $\mathrm{H}_{2} \mathrm{~S}$ og veikinda og sýna að sumir hópar eru ef til vill viðkvæmari en aðrir fyrir áhrifum $\mathrm{H}_{2} \mathrm{~S}$ á heilsu.

Enn önnur rannsókn hefur verið gerð á mögulegum áhrifum loftmengunar í Reykjavík og koma/innlagna á Landspítala. ${ }^{45}$ Sú rannsókn sýndi fram á samband milli hækkunar í styrk $\mathrm{O}_{3}$ og koma/innlagna á spítalann vegna hjartasjúkdóma, lungnasjúkdóma eða heilablóðfalls sama dag og allt að tveimur dögum eftir hækkun í $\mathrm{O}_{3}$. Pessi hækkun var $4 \%$ en var enn hærri meðal kvenna (8\%).

\section{Rannsóknir á áhrifum eldgosa á heilsufar manna}

Tvær vísindarannsóknir voru gerðar á áhrifum Eyjafjallajökulsgoss á heilsufar manna. Rannsókn Hanne Krage Carlsen og félaga sagði frá bráđum áhrifum eldgossins á heilsufar heimamanna. Á svæðinu sunnan og austan Eyjafjallajökuls varð mikið öskufall og allt að $25 \%$ öskunnar var af peirri stærð að hún gat komist alla lendingar spurningalistum um heilsufar 6-9 mánuðum eftir eldgosið og til samanburðar voru Skagfirðingar. Meiri líkur voru á að hafa fundið fyrir einkennum hjá rannsóknarhópi heldur en samanburðarhópi. Algengara var að pau væru með pyngsli fyrir brjósti, hósta, uppgang og augnertingu. Pegar horft var til baka síðustu 12 mánuði voru öndunarfæraeinkenni eins og hósti og uppgangur algengari hjá rannsóknarhópi en samanburðarhópi pótt tíðni lungnasjúkdóma eins og astma væri svipuð í báðum hópum. Helmingi fleiri í rannsóknarhópi höfðu tvö eða fleiri einkenni frá nefi, augum eða efri öndunarfærum.

Gerð var rannsókn á tengslum loftmengunar á Reykjavíkursvæðinu við komur á bráđadeild Landspítala árin 2007 til 2012. Loftmengunin fór yfir heilsufarsmörk 115 daga af 2191 á rannsóknartímanum og í 20 daga af tímabilinu var hún talin stafa af gosösku. Há gildi loftmengunar vegna eldfjallaösku tengdust ekki marktækt komum á bráðadeild. Höfundar ályktuðu að rannsóknin benti til pess að eldfjallaaska væri hættulegri en önnur tegund loftmengunar en rannsóknin skæri ekki endanlega úr um pað og frekari rannsókna væri pörf. ${ }^{48}$

Árið 2017 var gefin út ítarleg skýrsla um áhrif eldgoss í Holuhrauni 2014-2015. ${ }^{49}$ Mikið magn brennisteinsdíoxíðs mældist í byggð og fór yfir heilsuverndarmörk. Starfsmönnum sem fóru í námunda 
við eldstöðvarnar vegna vinnu sinnar var boðið að mæta í heilsufarsskoðun. Alls voru 32 einstaklingar (par af 6 konur) rannsakaðir fyrir ferð að gosstöðvunum. Eftir ferð að gosstöðvunum mættu 17 til endurmats. Af peim sem mættu í grunnrannsókn greindi um helmingur frá pví að hafa verið með erting í augum og nefi meðan á dvöl stóð við gosstöðvarnar og priðjungur var með kvefeinkenni. Eftir að komið var frá gosstöðvunum gengu pessi einkenni hins vegar í flestum tilfellum til baka. Ekki mældust marktækar breytingar á lungnastarfsemi eða merki um bólgu í öndunarvegum pessara einstaklinga eftir komuna frá eldstöðvunum. Einnig var gerð rannsókn á almenningi par sem gögn voru sótt úr gagnagrunnum Embættis landlæknis varðandi sjúkdómsgreiningar á heilbrigðistofnunum á Íslandi sem endurspegla möguleg áhrif af brennisteinsdíoxíði. Að auki voru upplýsingar sóttar í lyfjagagnagrunn Embættis landlæknis um sölu lyfseðilsskyldra astmalyfja. Við mat á mengun af völdum brennisteinsdíoxíðs voru notuð gögn frá Umhverfisstofnun frá mælistöðvum víðs vegar um land. Niðurstöður leiddu í ljós að á svæðum par sem aukinn styrkur brennisteinsdíoxíðs mældist varð marktæk aukning á aðsókn einstaklinga til heilbrigðispjónustunnar með öndunarfæravandamál. Hins vegar varð ekki marktæk aukning á greiningum sem tengdust ertingu í augum, höfuðverk, hjarta og æðasjúkdómum eða magaverkjum. Einnig sást marktæk aukning í sölu astmalyfja pá daga sem $\mathrm{SO}_{2}$ mældist yfir 24-klst loftgæðamörkum, einkum á höfuðborgarsvæðinu. Grein í vísindatímariti um pessar niðurstöður birtist nýlega. ${ }^{50}$

\section{Er pörf á frekari rannsóknum á loftmengun á Íslandi?}

Ríkisendurskoðun gaf út skýrslu um loftmengun á Íslandi. Par kom fram að hér á landi hafa Umhverfisstofnun og heilbrigðisnefndir sveitarfélaga haft forgöngu um að mæla, skrá og miðla upplýsingum um loftgæði. Ekki hefur pó verið staðið skipulega að skráningu og rannsóknum á heilsufarslegum áhrifum loftmengunar enda er ábyrgð á peim verkefnum óljós. Að mati Ríkisendurskoðunar er æskilegt að rannsóknum á áhrifum loftmengunar á heilsufar verði betur sinnt og að fylgst verði með peim með markvissari hætti en gert hefur verið. Ríkisendurskoðun taldi að hafa ætti í huga að markmið gildandi laga sem taka til loftgæða og loftmengunar væri að vernda heilsu almennings. Án áreiðanlegra upplýsinga og gagna um áhrif pessara pátta á lýðheilsu yrði erfitt að meta raunverulegan árangur af stefnu og aðgerðum stjórnvalda. Umhverfisráðuneytið tekur undir pessa hvatningu Ríkisendurskoðunar í áætlun um loftgæði 2018-2029 um að styrkja rannsóknir á loftgæðum og áhrifum peirra á heilsufar og efla pau kerfi sem skrá og miðla upplýsingum um próun loftgæða og áhrif peirra á heilsufar. ${ }^{4}$ Par kemur fram að prátt fyrir að flestar íslenskar rannsóknir sýni fram á samband milli loftmengunar og heilsufarsbrests eru pær ekki nógu margar til að geta svarað með vissu peirri spurningu hvort um sé að ræða orsakasamband eða ekki. Petta parf pví að rannsaka enn betur til að geta ályktað um petta samband.

\section{Samantekt}

Loftmengun getur verið af völdum manna eða náttúruleg eins og í eldgosum, á jarðhitasvæðum og í foki jarðvegsefna. Loftmengun er hættuleg heilsu manna, einkum peirra sem pjást af sjúkdómum í öndunarfærum og hjarta- og æðakerfi, og dregur úr lífsgæðum og lífslíkum. Mikilvægt er fyrir Íslendinga að vera á varðbergi gagnvart loftmengun og auka rannsóknir á peim til muna.

\section{Heimildir}

1. Lög um hollustuhætti og mengunarvarnir, nr. 7/1998

2. Sólnes J, Sigmundsson F, Bessason B. Edfjallavá. Náttúruvá á Íslandi - Eldgos og jarðskjálftar. Viðlagatrygging Íslands/Háskólaútgáfan, Reykjavík 2013: 73-175.

3. Guðmundsson G, Larsen G. Áhrif eldgosa á heilsu manna á Íslandi. Yfirlitsgrein. Læknablaðið 2016; 102: 433-41.

4. Umhverfisstofnun. Hreint loft til framtíðar - Áætlun um loftgæði á Íslandi 2018-2029. Umhverfis- og auðlindaráðuneytið, Reykjavík 2017; 1-62.

5. Air quality in Europe - 2018 report. European Environment Agency. eea.europa.eu/publications/air-quality-ineurope-2018 - júní 2019.

6. WHO. Ambient air pollution: A global assessment of exposure and burden of disease. Alpjóðaheilbrigðisstofnunin Genf 2016: 1-121.

7. Institute for Health Metrics and Evaluation's Global Burden of Disease Project og Health Effects Institute. State of the global air /2017 - a special report on global exposure to air pollution and its disease burden. stateofglobalair. org/sites/default/files/SOGA2017_report.pdf - janúar 2019.

8. WHO. Protecting children's health in a changing environment. Report of the Fifth Ministerial Conference on Environment and Health. Kaupmannahöfn 2010.

9. Iceland's Implementation of the 2030 Agenda for Sustainable Development. Voluntary National Review. Forsætisráðuneytið. Reykjavík 2019. heimsmarkmidin.is/ library/Heimsmarkmid/VNR_skyrsla_web

10. EEA core set of indicators - Guide. European Environment Agency. eea.europa.eu/publications/technical report_2005_1 - febrúar 2019.
11. Mannucci PM, Harari S, Martinelli I, Franchini M. Effects on health of air pollution: a narrative review. Intern Emerg Med 2015; 10: 657-62.

12. Alias C, Benassi L, Bertazzi L, Sorlini S, Volta M, Gelatti U. Environmental exposure and health effects in a highly polluted area of Northern Italy: a narrative review. Environ Sci Pollut Res 2019; 26: 4555-69.

13. Yang B-Y, Qian Z, Howard SW, Vaughn MG, Fan S-J, Liu $\mathrm{K}-\mathrm{K}$, et al. Global association between ambient air pollution and blood pressure: A systematic review and metaanalysis. Environ Pollut 2018; 235: 576-88.

14. Requia WJ, Adams MD, Arain A, Papatheodorou S, Koutrakis P, Mahmoud M. Global Association of Air Pollution and Cardiorespiratory Diseases: A Systematic Review, Meta-Analysis, and Investigation of Modifier Variables. Am J Public Health 2017; 108: S123-30.

15. Peters A, Dockery DW, Muller JFE, Mittleman MA. Increased Particulate Air Pollution and the Triggering of Myocardial Infarction. Circulation 2001; 103: 2810-5.

16. Hong Y-C, Lee J-T, Kim H, Ha E-H, Schwartz J, Christian DC. Effects of air pollutants on acute stroke mortality. Environ Health Perspect 2002; 110: 187-91.

17. Mustafić H, Jabre P, Caussin C, Murad MH, Escolano S, Tafflet M, et al. Main Air Pollutants and Myocardial Infarction: A Systematic Review and Meta-analysis. JAMA 2012; 307: 713-21.

18. Di Q, Wang Y, Zanobetti A, Wang Y, Koutrakis P, Choirat C, et al. Air Pollution and Mortality in the Medicare Population. N Engl J Med 2017; 376: 2513-22.

19. Sun Z, Zhu D. Exposure to outdoor air pollution and its human health outcomes: A scoping review. PLOS ONE 2019; 14: e0216550.
20. Kelly FJ, Fussell JC. Air pollution and public health: emerging hazards and improved understanding of risk. Environ Geochem Health 2015; 37: 631-49.

21. Rajak R, Chattopadhyay A. Short and long-term exposure to ambient air pollution and impact on health in India: a systematic review. Int J Environ Health Res 2019; 1-25.

22. Brunekreef B, Forsberg B. Epidemiological evidence of effects of coarse airborne particles on health. Eur Respir J 2005; 26: 309-18.

23. Di Q, Dai L, Wang Y, Zanobetti A, Choirat C, Schwartz JD, et al. Association of Short-term Exposure to Air Pollution With Mortality in Older Adults. JAMA 2017; 318: 2446-56.

24. McConnell R, Berhane K, Gilliland F, London SJ, Islam $\mathrm{T}$, Gauderman WJ, et al. Asthma in exercising children exposed to ozone: a cohort study. Lancet 2002; 359: 386-91.

25. Manan NA, Aizuddin AN, Hod R. Effect of Air Pollution and Hospital Admission: A Systematic Review. Ann Glob Health 2018; 84: 670-8.

26. Gauderman WJ, Avol E, Gilliland F, Vora H, Thomas D, Berhane K, et al. The Effect of Air Pollution on Lung Development from 10 to 18 Years of Age. N Engl J Med 2004; 351: 1057-67.

27. Bates MN, Garrett N, Crane J, Balmes JR. Associations of ambient hydrogen sulfide exposure with self-reported asthma and asthma symptoms. Environ Res 2013; 122: 81-7.

28. Bates MN, Garrett N, Shoemack P. Investigation of health effects of hydrogen sulfide from a geothermal source. Arch Environ Health 2002; 57: 405-11. 
29. Bates MN, Crane J, Balmes JR, Garrett N. Investigation of Hydrogen Sulfide Exposure and Lung Function, Asthma and Chronic Obstructive Pulmonary Disease in a Geothermal Area of New Zealand. PLOS ONE 2015; 10 e0122062.

30. Tzivian L. Outdoor air pollution and asthma in children. J Asthma Off J Assoc Care Asthma 2011; 48: 470-81.

31. Kwon OK, Kim SH, Kang SH, Cho Y, Oh IY, Yoon $\mathrm{CH}_{\text {, }}$ et al. Association of short- and long-term exposure to ai pollution with atrial fibrillation. Eur J Prev Cardiol 2019; 26: 1208-16.

32. WHO. Health aspects of air pollution with particulate matter, ozone and nitrogen dioxide : report on a WHO working group, Bonn, Germany 13-15 January 2003. apps. who.int/iris/handle/10665/107478 - júní 2019.

33. Arnalds Ó. Dust sources and deposition of aeolian materials in Iceland. Icel Agric Sci 2010; 23: 3-21.

34. Henry JG, Heinke GW. Environmental Science and Engeneering. Önnur útgáfa. Prentice Hall, New Jersey 1996.

35. Bell Michelle L, Davis Devra L, Fletcher Tony. A retrospective assessment of mortality from the London smog episode of 1952: the role of influenza and pollution Environ Health Perspect 2004; 112: 6-8.

36. Tilskipun Evrópupingsins og ráđsins um gæði andrúmslofts og hreinna lofts í Evrópu, nr. 2008/50/EB. 2008

37. Tilskipun Evrópupingsins og ráðsins um arsen, kadmíum kvikasilfur, nikkel og fjölhringa, arómatísk vetniskolefni andrúmslofti, nr. 2004/107/EC. 2004.
38. Pórðardóttir S, Jóhannesson §. Blý í blóði manna í Reykjavík. Læknablaðið 1993; 79: 403-8.

39. Jóhannsson P. Svifryksmengun í Reykjavík [Meistararitgerð verkfræðideild]: Háskóli Íslands 2007.

40. Steinarsdóttir SS, Ólafsdóttir KL. Loftgæðin í Reykjavík 2018 og áramótin 2018/2019 - Ársskýrsla heilbrigðiseftirlits Reykjavíkur um loftgæði. reykjavik.is/sites/default/ files/ymis_skjol/skjol_utgefid_efni/loftgaedin_i_reykjavik_2018_og_aramotin_2019.pdf - september 2019.

41. Carlsen HK, Zoëga $H$, Valdimarsdóttir $U$, Gíslason $T$, Hrafnkelsson B. Hydrogen sulfide and particle matter levels associated with increased dispensing of anti-asthma drugs in Iceland's capital. Environ Res 2012; 113: 33-9.

42. Finnbjornsdottir RG, Zoëga $\mathrm{H}$, Olafsson $\mathrm{O}$, Thorsteinsson $\mathrm{T}$, Rafnsson V. Association of air pollution and use of glyceryl trinitrate against angina pectoris: a population based case-crossover study. Environ Health 2013; 12: 38.

43. Finnbjornsdottir RG, Carlsen HK, Thorsteinsson T, Oudin 3A, Lund SH, Gislason T, o.fl. Association between Daily Hydrogen Sulfide Exposure and Incidence of Emergency Hospital Visits: A Population-Based Study. PLOS ONE 2016; 11: e0154946.

44. Finnbjornsdottir RG, Oudin A, Elvarsson BT, Gislason $\mathrm{T}$, Rafnsson V. Hydrogen sulfide and traffic-related air pollutants in association with increased mortality: a casecrossover study in Reykjavík, Iceland. BMJ Open 2015; 5 : e007272.
45. Carlsen HK, Forsberg B, Meister K Gíslason T, Oudin A. Ozone is associated with cardiopulmonary and stroke emergency hospital visits in Reykjavík, Iceland 2003-2009. Environ Health 2013; 12: 28.

46. Carlsen HK, Gislason T, Benediktsdottir B, Kolbeinsson TB, Hauksdottir A, Thorsteinsson T, et al. A survey of early health effects of the Eyjafjallajökull 2010 eruption in Iceland: a population-based study. BMJ Open 2012; 2: e000343.

47. Carlsen HK, Hauksdottir A, Valdimarsdottir UA, Gíslason T, Einarsdottir G, Runolfsson $\mathrm{H}$, et al. Health effects following the Eyjafjallajökull volcanic eruption: a cohort study. BMJ Open 2012; 2: e001851.

48. Carlsen $\mathrm{HK}$, Gislason $\mathrm{T}$, Forsberg $\mathrm{B}$, Meister $\mathrm{K}$ Thorsteinsson T, Jóhannsson T, et al. Emergency Hospital Visits in Association with Volcanic Ash, Dust Storms and Other Sources of Ambient Particles: A Time-Series Study in Reykjavík, Iceland. Int J Environ Res Public Health 2015; 12: 4047-59.

49. Sigurðsson BD, Stefánsdóttir G. Áhrif Holuhraunsgossins á umhverfi og heilsu. Rit LbhÍ nr 83. 2017; 1-115.

50. Carlsen HK, Aspelund T, Briem H, Gislason T, Jóhannsson $\mathrm{T}$, Valdimarsdóttir U, o.fl. Respiratory health among professionals exposed to extreme $\mathrm{SO} 2$ levels from a volcanic eruption. Scand J Work Environ Health 2019; 45: 312-5.

\section{Air pollution in Iceland and the effects on human health. Review}

\section{Gunnar Guðmundsson ${ }^{1,2}$ \\ Ragnhildur Guðrún Finnbjörnsdóttir ${ }^{3,4}$ \\ Porsteinn Jóhannsson ${ }^{3}$ \\ Vilhjálmur Rafnsson ${ }^{4}$}

This review is on air pollution in Iceland and how it affects human health. Air pollution can be described as a condition, where levels of compounds in the atmosphere are so high that it has undesirable or harmful effects on the general public or undesirable effects on the nature, flora and fauna, or man-built structures. Air pollution can have anthropogenic sources such as burning of fossil fuels, or natural sources such as volcanic eruptions, geothermal areas, and resuspension of soil (sandstorms). Air pollution decreases quality of health and shortens the lifespan. The health effects of air pollution can be divided into direct effects on health where, air pollution causes diseases and indirect effects, where air pollution increases symptoms of underlying diseases. Health protection limits are defined for certain ambient air pollutants. They are to act as reference levels for safe for individuals and are put forth to protect long-term human health. Outdoor air quality has been measured on a regular basis in Reykjavik since 1986 . For the first years, only $\mathrm{PM}_{10}$ was measured on a single station, but over the years the number of pollutants measured has increased and more measuring stations have been added.

In Iceland air quality is considered very good in general and the ambient pollutant concentrations are usually within defined limits. This is explained by multiple factors such as size of the country and other geographical features as well as weather conditions. Natural disasters can cause increased air pollutant concentrations, as recent volcano eruptions have shown. Several studies have been conducted on the association of air pollution and health of the Icelandic population, but it is essential that this association be examined further to increase the knowledge of adverse health effects of air pollution in Iceland.

'Department of Respiratory Medicine, Landspitali University Hospital, ${ }^{2}$ Department of Pharmacology and Toxicology, Faculty of Medicine, University of Iceland, ${ }^{3}$ The Environment Agency of Iceland, team for climate change and air pollution, ${ }^{4} \mathrm{Center}$ of Public Health, Faculty of Medicine, University of Iceland.

Key words: Air pollution, Particulate matter, review, health effects.

Correspondence: Gunnar Guðmundsson, ggudmund@landspitali.is 